\title{
ENERGY GAINS OF Eucalyptus BY TORREFACTION PROCESS
}

\author{
Erica Leonor Romão ${ }^{1, \$}$ \\ https://orcid.org/0000-0002-3038-4477 \\ Rosa Ana Conte ${ }^{2}$ \\ https://orcid.org/0000-0003-3376-3584
}

\begin{abstract}
The aim of this study was to evaluate the changes in the characteristics of Eucalyptus spp. from Paraíba Valley region, Sao Paulo - Brazil after torrification process. Torrification is a thermochemical process that occurs at temperatures lower than the pyrolysis process as a pretreatment to improve biomass characteristics for use as biofuel energy in power generation. An experimental study was carried out in a batch reactor at three temperatures $\left(240^{\circ} \mathrm{C}, 260^{\circ} \mathrm{C}\right.$ and $\left.280^{\circ} \mathrm{C}\right)$ with residence time of 30 and 60 minutes. At the indicated operating conditions by elemental analysis, higher heating value and thermogravimetric analysis were evaluated. Result showed that there was a reduction in the oxygen/carbon $(\mathrm{O} / \mathrm{C})$ and hydrogen/carbon $(\mathrm{H} / \mathrm{C})$ ratios, causing an increase in the thermal energy quality of torrified wood, about of $28 \%$ and $47 \%$ at temperatures of $260{ }^{\circ} \mathrm{C}$ with residence time of 60 minutes and $280{ }^{\circ} \mathrm{C}$ with 30 minutes, respectively. A thermogravimetric analysis showed that at $260{ }^{\circ} \mathrm{C}$ the hemicellulose was almost completely degraded leaving the fuel in better conditions for combustion or gasification processes.
\end{abstract}

Keywords: Biomass, biofuel, Eucalyptus spp., thermogravimetric, torrefaction.

\section{INTRODUCTION}

The use of biomass for power generation has attracted the attention of several countries and researchers. This is because biomass is a renewable resource and can be used in some processes to replace fossil resources (Sami et al. 2001). In Brazil, biomass has been used for energy generation through the combustion process, being sugarcane bagasse, firewood and charcoal widely used. However, wood has a higher preference over because it contains more energy, has a higher yield per area and is considered a neutral biomass, that is it has a closed cycle in $\mathrm{CO}_{2}$ generation (Van der Stelt et al. 2011, Arias et al. 2008), reducing environmental pollution and the greenhouse effect.

Brazil had an area of planted trees of 7,84 million hectares in 2016, with 5,67 million hectares of Eucalyptus planted area, 1,58 million hectares with pine and 0,59 of other species. Of the total Eucalyptus plantation $41 \%$ is located mainly in the southeastern region, $17 \%$ in the state of São Paulo, second largest Eucalyptus producer in the country behind only the state of Minas Gerais. In the last five years the Eucalyptus plantation area has been growing around $2,4 \%$ per year, while the pine plantation has been falling at a rate of $0,7 \%$ per year. Of the total Eucalyptus planted area, $14 \%$ goes to the steel industry as charcoal (IBA 2017). A strong advance in the forest area aimed to produce short rotation forests ( 2 to 3 years), at the same cost as a traditional forest and double the yield, reaching up to $55 \mathrm{TBS} \cdot \mathrm{ha}^{-1}$ (TBS - ton of dry biomass per hectare), referred to as

\footnotetext{
${ }^{1}$ Universidade de São Paulo, Escola de Engenharia de Lorena, Department of Basic and Environmental Sciences, São Paulo, Brazil. ${ }^{2}$ Universidade de São Paulo, Escola de Engenharia de Lorena, Department of Materials Engineering, São Paulo, Brazil.

•Corresponding author: ericaromao@usp.br

Received: 07.01.2020 Accepted: 29.08.2020
} 
energy forests (Eufrade et al. 2016, Couto and Dube 2001). Eucalyptus spp. is a promising biomass due to its good adaptation in different climatic variations and different species can be used. Ramos-Carmona et al. 2017, comments in his work on the use of fast-growing wood species in Colombia, such as Pinus patula, for use in power generation through the torrefaction process.

However, the use of biomass such as wood has some difficulties considering its direct use as fuel, such as low energy density, which is attributed to the high moisture content, high oxygen/carbon $(\mathrm{O} / \mathrm{C})$ ratio leading to low thermal efficiency compromising the calorific power. Biomass also has a fibrous characteristic, making the grinding process difficult, it is hydrophilic causing an increase in transportation costs, handling and storage difficulties, compromising its use in industrial and residential applications through the combustion and gasification process (Saidur et al. 2011).

One way of improving the properties of biomass is to convert it into biofuel through a pretreatment. That can reduce the inconvenience of raw biomass. Torrefaction is a thermal process that occurs between $200{ }^{\circ} \mathrm{C}$ to $300{ }^{\circ} \mathrm{C}$, operating with low heating rates under inert atmosphere. During the torrefaction of biomass three products are generated: a) the non-condensable gases, mainly $\mathrm{CO}_{2}$ and $\mathrm{CO}$; b) the condensed liquid, which is mostly composed of water moisture and acetic acid; and c) the solid product - torrefied biomass - in a dark brown color (Bergman et al. 2004).

Torrefaction causes changes in the physicochemical properties of biomass. At the beginning of the heating process biomass loses unbound water and as the temperature rises above $160{ }^{\circ} \mathrm{C}$ it loses bound water through chemical reactions forming $\mathrm{CO}_{2}$. During heating at $180{ }^{\circ} \mathrm{C}$ to $270{ }^{\circ} \mathrm{C}$ hemicellulose decomposes and water, $\mathrm{CO}_{2}$, acetic acid and phenols are lost leading to a darker, more toast-colored biomass (Bergman et al. 2004). The volatile compounds have a low calorific value resulting in an increase of the energy density of torrefied biomass. Arias et al. (2008) reported in their work a significant improvement and reduction of energy consumption in the milling step of the torrefied wood; this is due to the reduction of the fibrous structure and the lower moisture content prolonging the wood durability during storage (Van der Stelt et al. 2011, Couto and Dube 2001, Saidur et al. 2011).

There are several studies reporting the effect of the main parameters of the torrefaction process on biomass but we could not identify reports on the characteristics of the Eucalyptus in the Paraíba Valley region in the main databases searched. There are many studies by a group of researchers evaluating the characteristics of the Eucalyptus in the state of Minas Gerais (Fialho et al. 2019, Figueiro et al. 2019, Pereira et al. 2013), but due to the climatic differences, soil type and form in the planting (Santana et al. 2008) it is important to know the behavior of biomass after torrefaction in the region that also has a significant Eucalyptus production. Therefore, the main objective of this work was to evaluate the characteristics of the of Eucalyptus spp. after the torrefaction process. Wood from the Paraíba Valley region, located in São Paulo State - Brazil, was studied because the State contributes to the production of Eucalyptus wood and seeks other applications for wood produced in the region besides production of paper and cellulose, furniture industry and firewood for industry. The samples were wood in their raw form (untreated) and treated/torrefied at temperatures of $240{ }^{\circ} \mathrm{C}, 260^{\circ} \mathrm{C}$ and $280{ }^{\circ} \mathrm{C}$ for 30 and 60 minutes. The characterization was performed by elemental analysis, measurement of higher heating value and thermogravimetric analysis, the latter being only in the intermediate temperature range of $260{ }^{\circ} \mathrm{C}$.

\section{MATERIAL AND METHODS}

The raw wood (w) used for torrefaction was Eucalyptus spp., in the form of chips with approximately 10 x $20 \mathrm{~mm}^{2}$ after industrial chopper, with $15 \%$ moisture content; the raw wood was dried at $100{ }^{\circ} \mathrm{C} \pm 5{ }^{\circ} \mathrm{C}$ for 24 hours aiming at a uniform moisture content of the samples. $300 \mathrm{~g}$ samples were used for each torrefaction reaction at temperatures of $240{ }^{\circ} \mathrm{C}, 260{ }^{\circ} \mathrm{C}$ and $280{ }^{\circ} \mathrm{C}$ with residence time of 30 and 60 minutes (Romão et al. 2016), in a batch reactor at Lorena School of Engineering laboratory, São Paulo, Brazil. The heating of the reactor starts at room temperature $\left(25^{\circ} \mathrm{C}\right)$ with a heating rate of approximately $5{ }^{\circ} \mathrm{C} \cdot \mathrm{min}^{-1}$ under nitrogen atmosphere. After reaching the temperature selected in the present study, the residence time starts which in the tests were 30 and 60 minutes. After the end of the reaction, the temperature is reduced for cooling and the torrefied sample is removed. Each treatment was carried out in duplicate. 


\section{Mass yield}

The mass yield was obtained according to Bridgeman and Jones (2008), dividing the final mass (torrefied wood - WT) by the initial mass (raw wood - W) for each torrefaction reaction and multiplying by 100 (in dry basis).

\section{Elemental analysis and higher heating value}

Elemental analysis was performed using a Perkin Elmer CHNS/O elemental analyzer (in dry basis), the oxygen being calculated by difference. Calorific value was determined in an IKA C2000 basic calorimeter pump according to ASTM D5865-19 (2019) the amount of heat released by combustion represented by mega joule per kilo of solids in dry basis $\left(\mathrm{MJ} \cdot \mathrm{kg}^{-1}\right)$.

\section{Thermogravimetric analysis}

Thermogravimetric analysis (TGA) and its derivative (DTG) were performed in a Perkin Elmer STA 6000 equipment under nitrogen gas atmosphere at a constant flow rate of $20 \mathrm{~mL} \cdot \mathrm{min}^{-1}$. The samples were ground and sieved and samples of $2,4 \mathrm{mg}$ were selected between sieves of 40 and 60 mesh for analysis. The heating started at $35^{\circ} \mathrm{C}$ up to $800^{\circ} \mathrm{C}$ at a rate of $10^{\circ} \mathrm{C} \cdot \mathrm{min}^{-1}$ to evaluate the thermal decomposition profile of raw (W) and torrified wood (WT). For this study samples treated at $260^{\circ} \mathrm{C}$ with residence times of 30 and 60 minutes (WT260-30 and WT260-60) were used because this temperature is typically for torrefaction processes (Romão et al. 2016, Da Silva et al. 2017, Arteaga-Pérez et al. 2015).

\section{RESULTS AND DISCUSSION}

During the torrefaction process changes occur in the main components of biomass due to the increase in temperature, initially affecting hemicellulose and, subsequently, cellulose and lignin. Table 1 shows the results obtained for mass yield, elemental analysis and higher heating value of raw and torrified wood at temperatures of $240{ }^{\circ} \mathrm{C}, 260{ }^{\circ} \mathrm{C}$ and $280{ }^{\circ} \mathrm{C}$ with residence time of $30 \mathrm{~min}$ and $60 \mathrm{~min}$. As expected, mass yield decreased from $88,5 \%$ to $62,8 \%$ as the temperature and time increased. The results showed that the temperature variation had a greater impact on the mass yield than the reaction time. Arias et al. (2008) also reported in their work, with Eucalyptus samples treated at the same temperature and residence time of 30 minutes, a reduction in mass yield, in the range of $82 \%$ to $61 \%$. Even increasing the residence time up to 2 hours there was no significant change in mass yield, mainly between $240^{\circ} \mathrm{C}$ and $260^{\circ} \mathrm{C}$. At the first 30 minutes is associated with the decomposition of more reactive components of hemicellulose. As the residence time increases, the carbon content increases, and the mass loss occurs due to the decomposition of the less reactive components of hemicellulose. This behavior was also observed by Cardona et al. (2019) and Arteaga-Pérez et al. (2015).

Table 1: Mass yield, elemental analysis and higher heating value of raw wood and torrefied wood in different temperatures and residence times.

\begin{tabular}{|c|c|c|c|c|c|c|c|}
\hline Item & $\begin{array}{c}\text { Wood } \\
(\mathrm{W})\end{array}$ & $\begin{array}{c}\text { WT } \\
(240-30)\end{array}$ & $\begin{array}{c}\text { WT } \\
(240-60)\end{array}$ & $\begin{array}{c}\text { WT } \\
(260-30)\end{array}$ & $\begin{array}{c}\text { WT } \\
(260-60)\end{array}$ & $\begin{array}{c}\text { WT } \\
(280-30)\end{array}$ & $\begin{array}{c}\text { WT } \\
(280-60)\end{array}$ \\
\hline Mass yield (\%) & - & 88,46 & 83,33 & 83,33 & 69,67 & 70,00 & 62,80 \\
\hline $\mathrm{C}(\%)$ & 45,52 & 51,10 & 49,42 & 52,24 & 57,14 & 53,95 & 58,11 \\
\hline $\mathrm{H}(\%)$ & 6,26 & 5,57 & 5,67 & 5,73 & 5,32 & 5,65 & 5,31 \\
\hline $\mathrm{O}(\%)$ & 46,13 & 41,61 & 43,57 & 35,97 & 36,47 & 37,05 & 25,78 \\
\hline $\mathrm{N}(\%)$ & 0,79 & 0,00 & 0,33 & 4,23 & 0,00 & 1,75 & 9,64 \\
\hline Ratio O/C & 0,76 & 0,61 & 0,66 & 0,52 & 0,48 & 0,52 & 0,33 \\
\hline Ratio H/C & 1,65 & 1,31 & 1,38 & 1,32 & 1,12 & 1,26 & 1,10 \\
\hline HHV (MJ $\left.\cdot \mathrm{kg}^{-1}\right)$ & 17,42 & 20,54 & 19,35 & 20,84 & 22,40 & 25,61 & 23,08 \\
\hline
\end{tabular}

The elemental analysis shows that the carbon content increases with the temperature and residence time while hydrogen and oxygen are reduced. The hydrogen content had a small reduction, while the oxygen of the wood treated at $280{ }^{\circ} \mathrm{C}$ for 60 minutes had a $44 \%$ reduction compared to the untreated wood. After the torrefac- 
tion process, part of the hydrogen and oxygen are removed from the biomass as water and light volatiles, while relatively more carbon is retained. As a consequence, the $\mathrm{O} / \mathrm{C}$ and $\mathrm{H} / \mathrm{C}$ ratios were reduced to $0,61-0,33$ and 1,10-1,31 respectively. Those reductions in the treated fuel will generate less smoke and water vapor during the combustion or gasification process (Saidur et al. 2011), increasing the higher heating value of the fuel and giving the hydrophobic characteristic to the treated wood. The calorific value is an important data for fuels energy applications. According to Table 1, the calorific value showed an increase of $28 \%$ and $47 \%$ in treatments at $260{ }^{\circ} \mathrm{C}$ for 60 minutes and $280{ }^{\circ} \mathrm{C}$ for 30 minutes, respectively, in relation to raw wood. The value obtained at $260{ }^{\circ} \mathrm{C}$ for 60 minutes was similar to that obtained by Arias et al. (2008) $\left(22,8 \mathrm{MJ}^{\circ} \mathrm{kg}^{-1}\right)$ using eucalyptus, but the value at $280^{\circ} \mathrm{C}$ for 30 minutes was higher than that of Arias et al. (2008) $\left(23,4 \mathrm{MJ}^{\circ} \mathrm{kg}^{-1}\right)$. In the present work the torrefaction carried out at $280{ }^{\circ} \mathrm{C}$ for 30 minutes showed the highest calorific value with a mass yield of $70 \%$, evidencing the effect of the temperature increase and short reaction time as also reported by Chen et al. (2015). At higher temperatures $\left(300^{\circ} \mathrm{C}\right)$ the cellulose also degrades that leads to an increase of the lignin (Da Silva et al. 2017) from this temperature onwards the pyrolysis process begins.

\section{Thermogravimetric analysis}

Thermogravimetric analysis (TGA) evaluates the stability to thermal degradation of the sample and the degradation rate as a function of temperature and time that lead to percentage of sample mass loss; DTG curves refer to the first derivative of the TGA curves and present the mass variation as a function of time, but recorded as a function of temperature. From these analyses it is possible to evaluate the behavior of the main components of biomass (hemicellulose, cellulose and lignin) that have different thermal behaviors, thus making possible to understand the torrefaction process.

Figure 1 presents the curves obtained by TGA and DTG of the raw and torrefied wood samples at $260{ }^{\circ} \mathrm{C}$ for 30 (Figure 1b) and 60 minutes (Figure 1c). As can be seen, as the temperature of the torrefaction process increases a mass reduction of the samples occurs. The curve indicated in Figure 1a presents three ranges of thermal degradation: the first between $30^{\circ} \mathrm{C}$ and $100{ }^{\circ} \mathrm{C}$ corresponding to section (1); the interval between (2) and (3) is attributed to wood drying - moisture loss. The other two bands (2) and (3) refer to the degradation of hemicellulose and cellulose, respectively. The second temperature range between $200{ }^{\circ} \mathrm{C}$ and $300{ }^{\circ} \mathrm{C} \mathrm{(2)}$ corresponds mainly to the thermal degradation of hemicellulose, the most reactive polymer, as discussed by several authors (Shen et al. 2010, Da Silva et al. 2017, Lu et al. 2013). The third temperature range (3) between $315^{\circ} \mathrm{C}$ and $400{ }^{\circ} \mathrm{C}$ corresponds to the degradation of cellulose and the lignin, a macromolecule composed of aromatic chains that is more resistant to thermal degradation when compared to hemicellulose and cellulose, and its weight loss varies from $150^{\circ} \mathrm{C}$ to $900{ }^{\circ} \mathrm{C}$ (Yang et al. 2007).
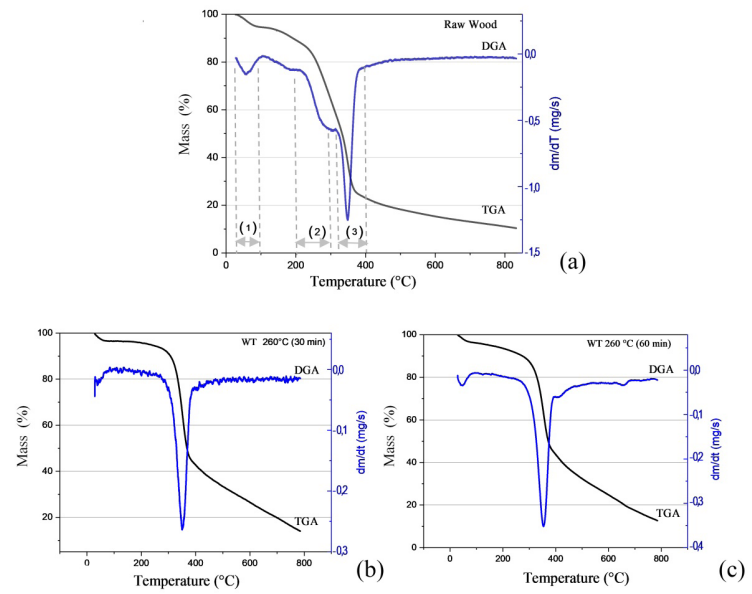

Figure 1: TGA / DTG curves of raw and torrefied wood at $260{ }^{\circ} \mathrm{C}$ for $30 \mathrm{~min}$ and $60 \mathrm{~min}$.

The two degradation bands (1) and (2) present in the raw wood related to the presence of moisture and the hemicellulose fraction, respectively, are not present in the torrefied wood samples - Figure 1(b) and Figure 1(c). The absence of the hemicellulose characteristic curve in the shoulder shape in torrefied wood indicates that hemicellulose was almost totally degraded during the heat treatment at $260^{\circ} \mathrm{C}$ because it is more reactive due to its amorphous structure (Tumuluru et al. 2010). The cellulose peak is still present due to its crystalline structure, more resistant to heat than hemicellulose (Yang et al. 2007). Figure 1(c) shows a small shoulder in 
the curve near the temperature of $400{ }^{\circ} \mathrm{C}$, suggesting a structural rearrangement in order to obtain a chemically reduced structure of the lignin, due to the fact that it is in an inert atmosphere at a high temperature. This modification does not lead to a significant reduction in lignin mass, as can be seen in the work by Da Silva et al. (2016).

\section{CONCLUSIONS}

According to the results it was verified that the Eucalyptus spp. wood from Paraíba Valley region of São Paulo State - Brazil had its characteristics improved by the torrefaction process aiming to its use as biofuel. Hydrogen and oxygen content reduction led to an increase of the HHV value up to $47 \%$ higher than raw wood.

Thermogravimetric analysis of torrified wood WT at $260{ }^{\circ} \mathrm{C}$ showed degradation of large part of the hemicellulose which favors an increase in the carbon content and the HHV value.

The torrefaction is a beneficial pretreatment for Eucalyptus spp. wood. It promotes changes in its chemical composition leading to an attractive renewable fuel for energy generation thus contributing to the reduction of greenhouse effect gases.

\section{ACKNOWLEDGMENTS}

The authors tank to: (I) Project support 2016/13852-3, São Paulo Research Foundation (FAPESP) (II) The Laboratório Associado de Combustão e Propulsão (LCP) do Instituto Nacional de Pesquisas Espaciais - INPE de Cachoeira Paulista, SP for elementar analysis.

\section{REFERENCES}

ASTM. 2019. Standard Test Method for Gross Calorific Value of Coal and Coke. ASTM D5865-19. 2019. ASTM International: West Conshohocken,, PA, USA. https://doi.org/10.1520/D5865_D5865M-19

Arias, B.R.; Pevida, C.G.; Fermoso, J.D.; Plaza, M.G.; Rubiera, F.G.; Pis Martinez, J.J. 2008. Influence of torrefaction on the grindability and reactivity of woody biomass. Fuel Process Technol 89(2): 169-175. https://dx.doi.org/10.1016/j.fuproc.2007.09.002

Arteaga-Pérez, L.E.; Segura, C.; Bustamante-García, V.; Cápiro, O.G.; Jiménez, R. 2015. Torrefaction of wood and bark from Eucalyptus globulus and Eucalyptus nitens: Focus on volatile evolution vs feasible temperatures. Energy 93: 1731-1741. https://doi.org/10.1016/j.energy.2015.10.007

Bergman, P.C.A.; Boersma, A.R.; Kiel, J.H.A.; Prins, M.J.; Ptasinski, K.J.; Janssen, F.J.J.G. 2004. Torrefaction for entrained-flow gasification of biomass. (ECN-C; Vol. 2005067). Energieonderzoek Centrum Nederland: Petten, Netherlands. https://pure.tue.nl/ws/portalfiles/portal/3167898/638046.pdf

Bridgeman, T.G.; Jones, J.M. 2008. Torrefaction of reed canary grass, wheat straw and willow to enhance solid fuel qualities and combustion properties. Fuel 87(6): 844-856. https://doi.org/10.1016/j.fuel.2007.05.041

Cardona, S.; Gallego, L.J.; Valencia, V.; Martinez, E.; Rios, L.A. 2019. Torrefaction of Eucalyptus-tree residues: A new method for energy and mass balances of the process with the best torrefaction conditions. Sustainable Energy Technologies and Assessments 31: 17-24. https://doi.org/10.1016/j.seta.2018.11.002

Chen, W.H.; Huang, M.Y.; Chang, J.S.; Chen, C.Y.; Lee, W.J. 2015. An energy analysis of torrefaction for upgrading microalga residue as a solid fuel. Bioresource Technology 185: 285-293. https://doi.org/10.1016/j.biortech.2015.02.095

Couto, L.; Dube, F. 2001. The status and practice of forestry in Brazil at the beginning of the 21st century: A review. Forest Chron 77(5): 817-830. https://doi.org/10.5558/tfc77817-5.

Da Silva, C.M.S.; Vital, B.R.; Carneiro, A.C.O.; Costa, E.V.S.; Magalhaes, M.A.; Trugilho, P.F. 2017. Structural and compositional changes in Eucalyptus wood chips subjected to dry torrefaction. Ind Crop Prod 109: 598-602. http://dx.doi.org/10.1016/j.indcrop.2017.09.010

Da Silva, C.M.S.; Carneiro, A.C.O.; Pereira, B.L.C.; Vital, B.R.; Alves, I.C.N.; Magalhães, M.A. 
2016. Stability to thermal degradation and chemical composition of woody biomass subjected to the torrefaction process. Eur J Wood Wood Prod 74(6): 845-850. https://doi.org/10.1007/s00107-016-1060-z

Eufrade, H.J.; Melo, R.X.; Sartori, M.M.P.; Guerra, S.P.S.; Ballarin, A.W. 2016. Sustainable use of eucalypt biomass grown on short rotation coppice for bioenergy. Biomass Bioenerg 90: 15-21. http://dx.doi.org/10.1016/j.biombioe.2016.03.037

Fialho, L.F.; Carneiro, A.C.O.; Carvalho, A.M.M.L.; Figueiró, C.G.; Da Silva, C.M.S.; Magalhães, M.A.; Peres, L.C. 2019. Bio-coal production with agroforestry biomasses in Brazil. Maderas-Cienc Tecnol 21(3): 357-366. http://dx.doi.org/10.4067/S0718-221X2019005000308

Figueiro, C.G.; Vital, B.R.; Carneiro, A.C.O.; Silva, C.M.S.; Magalhães, M.A.; Fialho, L.F. 2019. Energy valorization of woody biomass by torrefaction treatment: A Brazilian experimental study. Maderas-Cienc Tecnol 21(3): 297-304. https://doi.org/10.4067/S0718-221X2019005000302

IBA. 2017. Relatório 2017. IBÁ: Brazil. 80p. https://iba.org/images/shared/Biblioteca/IBA_RelatorioAnual2017.pdf

Lu, K.M.; Lee, W.J.; Chen, W.H.; Lin, T.C. 2013. Thermogravimetric analysis and kinetics of co-pyrolysis of raw/torrefied wood and coal blends. Appl Energ 105: 57-65. http://dx.doi.org/10.1016/j.apenergy.2012.12.050

Pereira, B.L.C.; Carneiro, A.C.O.; Carvalho, A.M.M.L.; Trugilho, P.F.; Melo, I.C.N.A.; Oliveira, A.C. 2013. Study of termal degradation of Eucalyptus wood by thermogravimetry and calorimetry. Rev Arvore 37(3): 567-576. http://www.redalyc.org/articulo.oa?id=48828116020

Ramos-Carmona, S.; Pérez, J.F.; Pelaez-Samaniego, M.R.; Barrera, R.; Garcia-Perez, M. 2017. Effect of torrefaction temperature on properties of Patula pine. Maderas-Cienc Tecnol 19(1): 39 - 50. http://dx.doi.org/10.4067/S0718-221X2017005000004

Romão, E.L.; Dias, I.A., Conte, R.A.; Pinatti, D.G. 2016. Avaliação do efeito da torrefação de biomassa lenhosa visando à produção de biocombustível para fins energéticos. In XXI Congresso Brasileiro de Engenharia Química - COBEQ, Fortaleza, CE, Brazil. (in portuguese). https://proceedings.science/cobeq/cobeq-2016/ papers/avaliacao-do-efeito-da-torrefacao-de-biomassa-lenhosa-visando-a-producao-de-biocombustivel-para--fins-energeticos

Saidur, R.; Abdelaziz, E.A.; Demirbas, A.; Hossain, M.S.; Mekhilef, S. 2011. A review on biomass as a fuel for boilers. Renew Sust Energ Rev 15(5): 2262-2289. https://doi.org/10.1016/j.rser.2011.02.015

Sami, M.; Annamalai, K.; Wooldridge, M. 2001. Co-firing of coal and biomass fuel blends. Prog Energ Combust 27(2): 171-214. https://doi.org/10.1016/S0360-1285(00)00020-4

Santana, R.C.; Barros, N.F.; Leite, H.G.; Comerford, N.B.; Novais, R.F. 2008. Biomass estimation of Brazilian eucalypt plantations. Rev Arvore 32(4): 697-706. https://doi.org/10.1590/S0100-67622008000400011

Shen, D.K.; Gu, S.; Bridgwater, A.V. 2010. The thermal performance of the polysaccharides extracted from hardwood: cellulose and hemicelluloses. Carbohydrate Polymers 82: 39-45. https://doi.org/10.1016/j.carbpol.2010.04.018

Tumuluru, J.S.; Sokhansanj, S.; Wright, C.T.; Boardman, R.D. 2010. Biomass Torrefaction Process Review and Moving Bed Torrefaction System Model Development. Idaho National Laboratory: USA. https://inldigitallibrary.inl.gov/sites/sti/sti/4734111.pdf

Van der Stelt, M.J.C.; Gerhauser, H.; Kiel, J.H.A.; Ptasinski, K.J. 2011. Biomass upgrading by torrefaction for the production of biofuels: A review. Biomass Bioenerg 35: 3748-3762. https://doi.org/10.1016/j.biombioe.2011.06.023

Yang, H.; Yan, R.; Chen, H.; Lee, D.H.; Zheng, C. 2007. Characteristics of hemicellulose, cellulose and lignin pyrolysis. Fuel 86: 1781-1788. https://doi.org/10.1016/j.fuel.2006.12.013 